\title{
Iron Homeostasis Disorder and Alzheimer's Disease
}

\author{
Yu Peng ${ }^{1}$, Xuejiao Chang ${ }^{1}$ and Minglin Lang ${ }^{1,2, *(1)}$ \\ 1 CAS Center for Excellence in Biotic Interactions, College of Life Science, University of Chinese Academy of \\ Sciences, Beijing 100049, China; pengyu18@mails.ucas.ac.cn (Y.P.); changxuejiao20@mails.ucas.ac.cn (X.C.) \\ 2 College of Life Science, Agricultural University of Hebei, Baoding 071000, China \\ * Correspondence: langml@ucas.ac.cn; Tel.: +86-10-6967-2639
}

check for

updates

Citation: Peng, Y.; Chang, X.; Lang, M. Iron Homeostasis Disorder and Alzheimer's Disease. Int. J. Mol. Sci. 2021, 22, 12442. https://doi.org/ 10.3390/ijms222212442

Academic Editor: Masaru Tanaka

Received: 16 October 2021

Accepted: 10 November 2021

Published: 18 November 2021

Publisher's Note: MDPI stays neutral with regard to jurisdictional claims in published maps and institutional affiliations.

Copyright: (c) 2021 by the authors. Licensee MDPI, Basel, Switzerland. This article is an open access article distributed under the terms and conditions of the Creative Commons Attribution (CC BY) license (https:// creativecommons.org/licenses/by/ $4.0 /)$.

\begin{abstract}
Iron is an essential trace metal for almost all organisms, including human; however, oxidative stress can easily be caused when iron is in excess, producing toxicity to the human body due to its capability to be both an electron donor and an electron acceptor. Although there is a strict regulation mechanism for iron homeostasis in the human body and brain, it is usually inevitably disturbed by genetic and environmental factors, or disordered with aging, which leads to iron metabolism diseases, including many neurodegenerative diseases such as Alzheimer's disease (AD). $\mathrm{AD}$ is one of the most common degenerative diseases of the central nervous system (CNS) threatening human health. However, the precise pathogenesis of AD is still unclear, which seriously restricts the design of interventions and treatment drugs based on the pathogenesis of AD. Many studies have observed abnormal iron accumulation in different regions of the AD brain, resulting in cognitive, memory, motor and other nerve damages. Understanding the metabolic balance mechanism of iron in the brain is crucial for the treatment of $\mathrm{AD}$, which would provide new cures for the disease. This paper reviews the recent progress in the relationship between iron and AD from the aspects of iron absorption in intestinal cells, storage and regulation of iron in cells and organs, especially for the regulation of iron homeostasis in the human brain and prospects the future directions for AD treatments.
\end{abstract}

Keywords: Alzheimer's disease; iron homeostasis disorder; iron homeostasis regulators; $\beta$-amyloid; tau; APP; central nervous system; oxidative stress; pathogenesis; genetic intervention

\section{Introduction}

The transition metal element iron is the second most abundant metal element in the earth's crust behind, aluminum. It is also an essential trace element and an important component of metalloprotein for human body [1,2]. Due to its unique chemical reaction characteristics, it plays an important role in maintaining normal physiological function and metabolism, such as oxygen transport, DNA synthesis, iron sulfur cluster synthesis, neurotransmitter synthesis and electron transfer in respiratory chain [3-5]. The adult human body contains 3-5 g of iron [2]. In the normal metabolism of the human body, iron ions are absorbed into the blood through the small intestine and transported to the parts of the body requiring iron. Although the body strictly regulates the regulation of iron metabolism, changes with age, genetics and the environment will lead to iron metabolism disorders [6]. The disorder of iron metabolism in the body will catalyze the formation of reactive oxygen species (ROS) through Fenton and other chemical reactions, attack DNA, protein and lipid molecules, and lead to cell damage [7,8]. In recent years, more and more research teams on the pathogenesis of Alzheimer's disease (AD) have shown that the oxidative stress induced by iron metabolism disorder and the production of ROS are related to the pathological process of AD [7,9]. Alzheimer's disease is an age-related neurodegenerative disease with clinical symptoms of memory decline, cognitive impairment and learning impairment [10-12]. With the increasing human life span, the incidence rate of AD is also increasing, and has become one of the most important fatal diseases $[5,13,14]$. The pathological features of $\mathrm{AD}$ in the brain are the extracellular deposition of $\mathrm{A} \beta$ proteins forming 
insoluble senile plaques and the intracellular accumulation of hyperphosphorylated tau proteins forming neurofibrillary tangles (NFTs), which result in a large degree of neuronal cell death $[11,15,16]$. Thus far, the main causes and pathogenesis of AD have not been fully clarified. Many research teams have found that there is regional deposition of iron in the brain of AD patients [17-19]; treatment with an iron chelator can effectively alleviate the symptoms of $\mathrm{AD}[9]$, suggesting that iron metabolism disorder has a close relationship with AD.

This paper reviews the relevant research progress in the field of iron and $\mathrm{AD}$ in recent years, focusing on the oxidative stresses induced by normal iron metabolism and its metabolic disorders, especially for abnormal expression of the iron transporters, transferrin receptors, divalent metal transporters, and their relationships with the AD pathological mark proteins, such as $\mathrm{A} \beta$ and tau proteins. Relevant contemporary AD treatment measures have also been discussed and prospected. The iron homeostasis on AD provides a theoretical basis for the prevention and treatment of neurodegenerative diseases and an effective drug screening target.

\section{Physiological Function and Metabolic Process of Systemic Iron}

\subsection{Physiological Function of System Iron}

Iron is an essential trace metal element and an important component of metalloprotein [2]. Due to its unique chemical reaction characteristics, iron plays an important role in oxygen transport, DNA synthesis and repair, energy generation and enzyme function, such as the formation of a variety of coordination compounds with organic ligands and redox reactions by the mutual conversion of divalent iron and trivalent iron $[3,6,8,20]$.

\subsection{Metabolic Process of System Iron}

\subsubsection{System Iron Absorption}

As we know, the adult human body contains about 3-5 g of iron [2], for individuals without blood transfusion, a part of the iron in the system comes from intestinal cells absorbed from food, and the other part comes from macrophages [6,21]. As shown in Figure 1, the absorption of iron from food is $\mathrm{Fe}^{3+}$, which is reverted to $\mathrm{Fe}^{2+}$ by DCYTB (duodenal cytochrome-b-like protein); then, the divalent metal transporter 1 (DMT1) on the surface of the intestinal cell membrane combines the ferrous iron and transports it into the intestinal epithelial cells [20]. The ferrous iron entering intestinal epithelial cells can be transported to mitochondria for heme molecule synthesis, or oxidized to ferric iron and stored in ferritins [22,23]. Excess $\mathrm{Fe}^{2+}$ is released into plasma by FPN (ferroportin) which is located on the basal intestinal cell membrane where it is again oxidated to $\mathrm{Fe}^{3+}$ by the same situated hephaestin [24-26].

As shown in Figure 2, $\mathrm{Fe}^{3+}$ in plasma can bind to transferrin (TF), which is transported through blood in the form of TF-Fe complex. The complex then bind to transferrin receptor 1 (TfR1) that highly expressed on the surface of iron demanding cell membrane, and it enters iron demanding cells through clathrin-mediated endocytosis $[27,28] . \mathrm{Fe}^{3+}$ in endocytic vesicles is reduced to $\mathrm{Fe}^{2+}$ by STEAP (six-transmembrane epithelial antigen of prostate) and released into cells by divalent metal ion transporter DMT1 after separation in low $\mathrm{pH}$ environment of endocytic vesicles [29-32]. In addition, ZIP14 (member of the Zrt/IRT family) was initially identified as a transporter of Zn. In subsequent studies, it was found to be involved in the transport of ferrous iron released from endocytic vesicles into the cytoplasm $[1,28,33]$. TF and TfR1 separated from $\mathrm{Fe}^{3+}$ enter the plasma and are redistributed to the surface of cell membrane to participate in iron transport and the next round of iron absorption, respectively [1]. $\mathrm{Fe}^{3+}$ in plasma can also combine with citrate, ATP and ascorbate to form small-molecule complexes [6].

\subsubsection{Storage and Loss of System Iron}

In the body, iron is mainly stored in liver cells and macrophages. Macrophages phagocytize the aging red blood cells and release the iron ions inside red blood cells; then, 
the released irons are stored in ferritin proteins in the macrophages [34]. When the body is in a state of iron demand, macrophages secrete ferritin protein into the serum circulatory system; therefore, the concentration of ferritin protein in serum can reflect the state of iron content in the body [35]. Ferritin protein plays an important role in iron storage and antioxidation in cells [36]. Ferritin protein contains two subunits of $\mathrm{H}$-ferritin and L-ferritin, which exhibit ferrous oxidase activity and iron storage function, respectively [37]. $\mathrm{Fe}^{2+}$ in cells is oxidized by H-ferritin and stored in L-ferritin. Each ferritin protein can store 4500 iron atoms, which can considerably reduce the cell level of free iron ions and prevent the damage caused by free-iron-induced oxidative stresses; thus, it has antioxidant effects [38]. When the concentration of iron in cells decreases, ferritin protein is decomposed into hemoxanthin by lysosomes. Hemoxanthin and ferritin protein can be detected by Prussian blue staining [39]. In addition to ferritin protein, iron entering the cell can enter mitochondria to synthesize heme, as well as the iron sulfur cluster, and participate in the process of aerobic respiration as a cofactor of mitochondrial respiratory chain protein. It can also combine with some small molecular substances in the cell, such as citric acid, ATP, AMP and pyrophosphate to form an intracellular free iron pool $[6,8,40]$. The amount of pooled free iron can reflect the change in iron content in cells, which can be detected by some fluorescence techniques [8]. Increasing the pool content will produce harmful substances through redox reactions, causing damage to cells, which could even lead to cell death when it is serious [8,41,42]. Iron entering the blood can also be ingested and utilized by iron cells and iron storage cells. Most of the iron in the blood is used by red blood cells to participate in the transport of oxygen. About $20-30 \%$ of the iron is stored in the liver and macrophages, and some iron is involved in the formation of myoglobin, cytochrome and iron-containing enzymes [8].

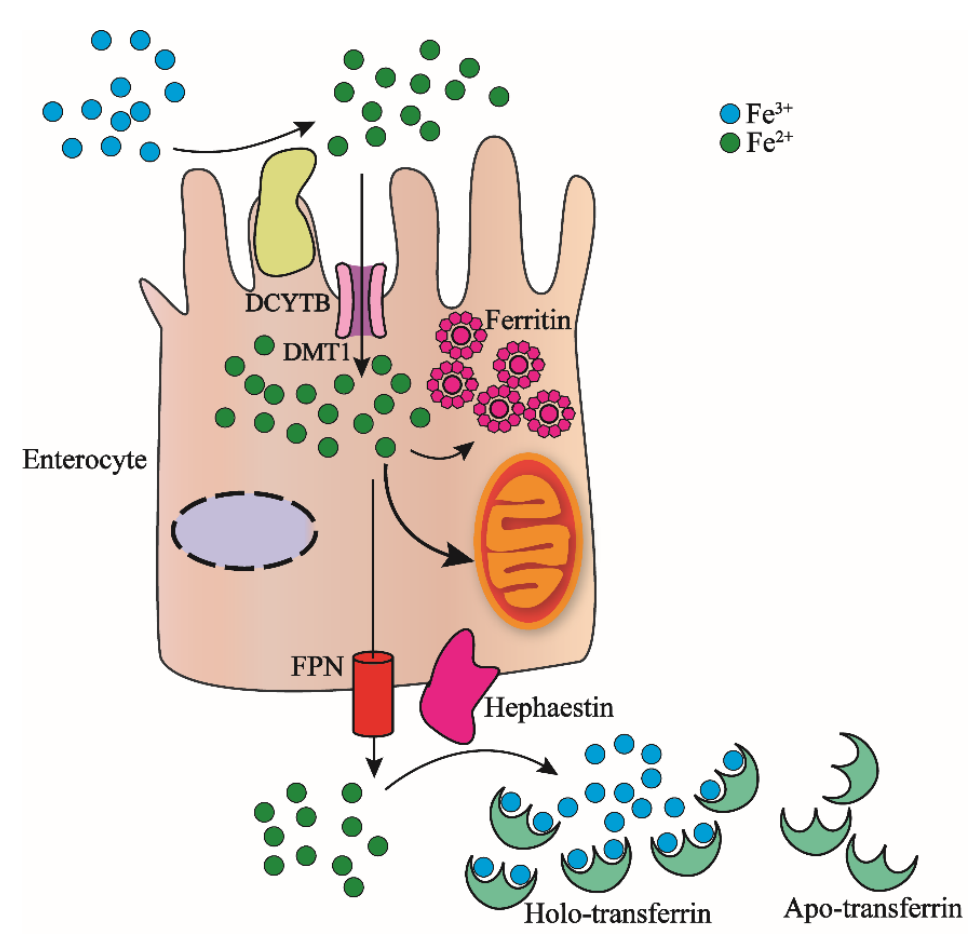

Figure 1. Nonheme iron intestinal absorption and transport by intestinal cells. Food $\mathrm{Fe}^{3+}$ is reduced to $\mathrm{Fe}^{2+}$ by DCYTB, which binds to the divalent metal transporter DMT1 on the surface of the intestinal cell membrane and transported into the intestinal epithelial cells. The $\mathrm{Fe}^{2+}$ that enters the intestinal cells can enter the mitochondria for the synthesis of heme. It can also be oxidized to $\mathrm{Fe}^{3+}$ and then stored in ferritin. The excess $\mathrm{Fe}^{2+}$ is released from FPN into the plasma and then oxidized to $\mathrm{Fe}^{3+}$ by hephaestin. Each molecule of Apo-transferrin in the plasma combines with two $\mathrm{Fe}^{3+}$ ions to form Holo-transferrin-Fe. The complex transports iron in the blood to the organs in the body that require iron. 


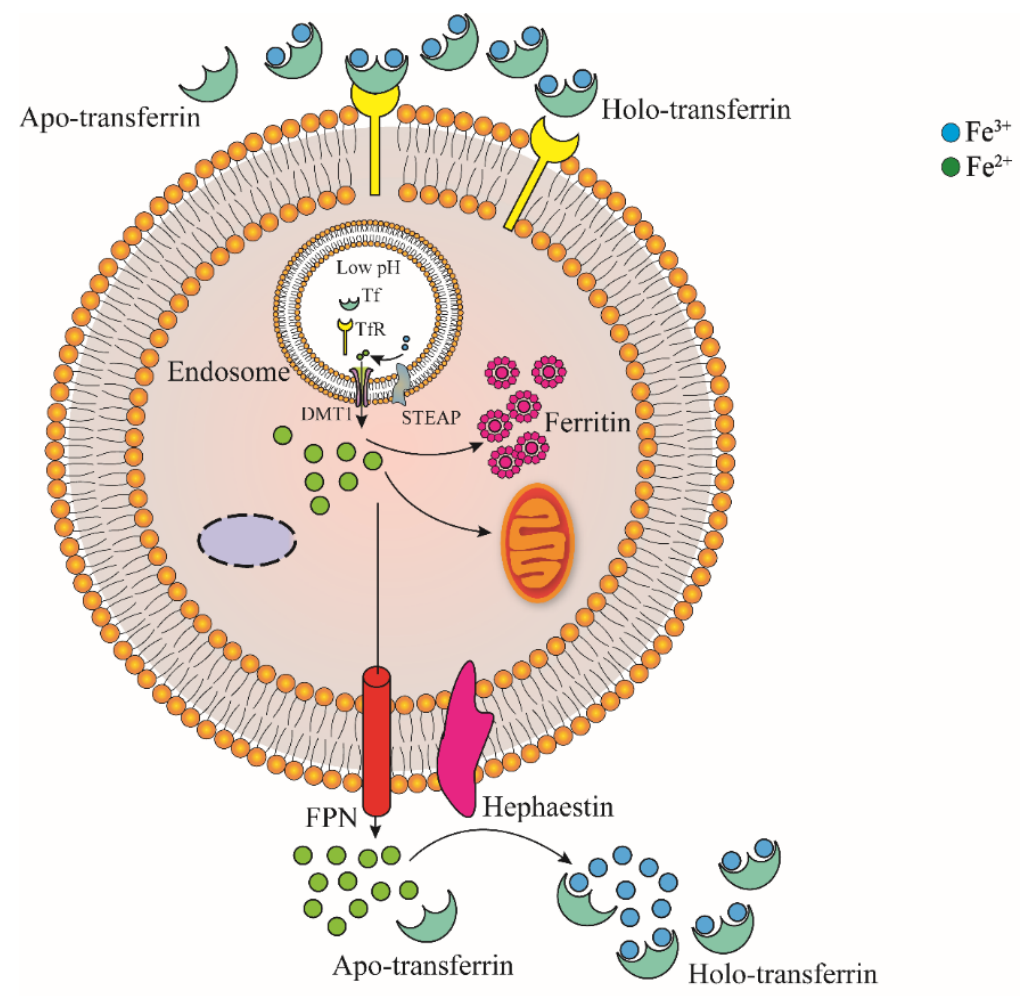

Figure 2. Somatic cell absorption and the transport of iron ions. $\mathrm{Fe}^{3+}$ in plasma can bind to Apotransferrin (Tf), which forms a Tf-Fe complex; then, it is transported through the blood to bind to the transferrin receptor (TfR1) that requires high expression on the surface of iron cell membranes, which enters the iron-requiring cells through endocytosis mediated by clathrin. In the endocytic vesicles, $\mathrm{Fe}^{3+}$ is reduced to $\mathrm{Fe}^{2+}$ by the six-transmembrane epithelial antigen of prostate (STEAP), After separation in a low-pH environment, $\mathrm{Fe}^{2+}$ is released into the cell by the divalent metal ion transporter DMT1. The iron ions in the cell can enter the mitochondria to participate in the redox reaction and can also be stored in the ferritin protein. When the body is in a state of iron limiting, $\mathrm{Fe}^{2+}$ can be transported to the outside of the cell through FPN and oxidized by hephaestin to $\mathrm{Fe}^{3+}$, and combines with Apo-transferrin to form Holo-transferrin.

The normal human body loses about $1-2 \mathrm{mg}$ of iron every day [36,43]. Iron in the body is mainly excreted from intestinal mucosa, skin cells, sweat and urine $[4,30,44]$.

\subsubsection{Regulation of Iron in Cells}

Iron regulatory proteins (IRPs) combine with iron regulatory elements (IREs) in the $3^{\prime}$ or $5^{\prime}$ untranslated region of mRNA transcripts of iron-metabolism-related genes to regulate the iron concentration in cells $[43,45,46]$. The IRE region contains a loop of $5^{\prime}-$ cagugn- $3^{\prime}$ folded by 30 nucleotides (in which the hydrogen bond formed between $\mathrm{G}$ and $\mathrm{C}$ stabilizes its structure), without pairing to form hydrogen bonds which will destroy this structure [8,46-48]. As shown in Figure 3, IREs are located at the $3^{\prime}$-UTR and 5'-UTR areas of TfR1 and DMT1 mRNAs, and ferroportin and ferritin mRNAs, respectively, although the binding of IRPs to IREs could finely regulate the iron concentration in cells [49]. When the concentration of iron ions in cells is too high, on the one hand, it will induce conformation changes in the untranslated region of TfR1 and DMT1 mRNAs, so that IRPs cannot bind to the IRE region, and those mRNAs are degraded, whereas the expression levels of ferroportin and ferritin proteins are increased; on the other hand, iron ions can bind to IRP1, forming iron sulfur clusters in IRP1 that exhibit cytoplasmic aconitase activity. In contrast, when the concentration of iron ions decreases, the binding ability between IRP and IRE is enhanced, the expression level of ferroportin and ferritin proteins will decrease, and the expression level of TfR1 and DMT1 will increase [48,50-52]. 


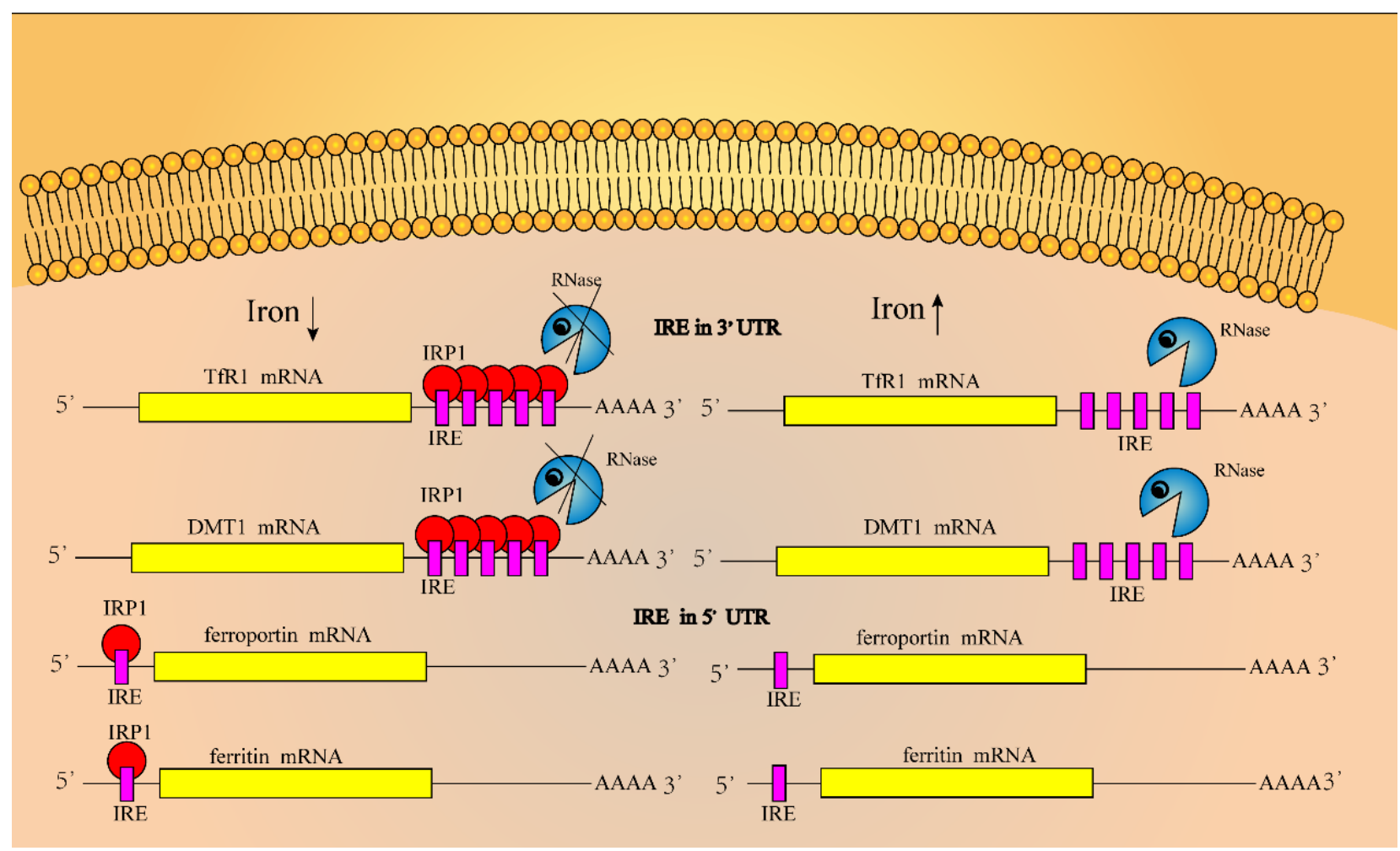

Figure 3. Regulation of iron homeostasis in cells. IREs are located in the $3^{\prime}$-UTR region of TfR1 and DMT1 mRNAs, whereas they are located in the $5^{\prime}$-UTR region of ferroportin and ferritin mRNAs. The combination of IRP and IRE regulates the iron ion concentration in the cell. When the iron ion concentration in the cell is too high, it will induce conformation changes in the untranslated region of mRNAs, making IRPs unable to bind to the IRE region; then, mRNAs of TfR1 and DMT1 are degraded, and the expression level of ferroportin and ferritin increases. On the other hand, iron ions bind to IRP1, and can form iron-sulfur clusters in IRP1 that exhibit cytoplasmic aconitase activity. In contrast, when the iron concentration in the cell decreases, the binding ability of IRP and IRE is enhanced, which leads to a decreased expression of ferroportin and ferritin proteins, and an increased expression of TfR1 and DMT1.

Iron regulatory proteins IRP1 and IRP2 are intracellular iron sensors. These are two proteins that are homologous proteins and belong to the iron-sulfur cluster isomerase family [53]. IRP1 can form a cis-aconitase-type iron sulfur cluster (4Fe-4S), which not only determines its functional mode, but also serves as an important regulatory site. IRP1 forms an iron sulfur cluster only when cells are rich in iron, in which IRP1 can display cis-aconitase activity in cytoplasm; however, it reduces the ability of IRP1 to bind to IRE. Low concentrations of iron in cells induce the depolymerization of iron sulfur clusters in IRP1 and enhance the ability of IRP1 to bind to IRE, although the mechanism of iron sulfur cluster depolymerization in IRP1 has not been fully illuminated. In addition, the increase in $\mathrm{NO}$ and $\mathrm{H}_{2} \mathrm{O}_{2}$ concentration in cells will activate the activity of IRP1 and promote its binding to IRE [38].

Iron ions and oxygen regulate the synthesis of IRP2 in cells through post-translational mechanisms. IRP2 has lost the activity of aconitase in the process of evolution. The decrease in intracellular iron ions and oxygen concentration promote the synthesis of IRP2 and maintain its stable state. In contrast, the increase in iron ion and oxygen concentration will accelerate the degradation of IRP2. The N-terminal 73 amino acid sequence of IRP2 is characteristic of IRP2. This highly conserved 73 amino acids is encoded by a determined exon and is related to the iron-dependent degradation of IRP2 [8].

\subsubsection{Regulation of Iron in the System}

Iron ions exported from the intestine are absorbed by the iron-demanding tissues and organs of the body through blood circulation. The liver is the main organ for the regulation 
of iron balance, which plays an important role in the regulation of whole-body iron balances [34]. The liver produces and secretes the hepcidin hormone [25,54], which is a short polypeptide composed of an 84 amino acid sequence encoded by the HAMP gene and a 25 amino acid sequence hydrolyzed by basic amino acid protein hydrolase [30,34,42,55-58]. When the iron in the body is in a high-concentration state, hepcidin combines with FPN protein and JAK2 on the intestinal epidermal cell membrane to form a complex, which is phosphorylated before the endocytosis of FPN. FPN is endocytosed into the cell and degraded in the lysosome after ubiquitination to reduce the concentration of iron in the blood $[30,46,55,59]$. In contrast, when the body is in a state of iron deficiency, hypoxia, inflammation and erythrocyte synthesis, the expression of hepcidin decreases. Some studies have shown that hepcidin can also be produced by other organs and tissue cells, such as the heart, alveolar macrophages and spleen macrophages [42,60-62]. In addition to the liver, red blood cells and macrophages participate in the iron metabolism of the body. For example, iron in red blood cells participates in the synthesis of hemoglobin, and macrophages can phagocytize aging red blood cells to release iron; therefore, macrophages could participate in iron circulation when the body is in a state of low iron concentration $[42,63]$.

\subsection{Roles of Microbiota in Iron Homeostasis and Neurodegenerative Diseases}

In mammals, iron ions are absorbed mainly through the duodenum, and there is a strict regulation mechanism for iron ion absorption. Iron ions that are not absorbed into the duodenum end up in the colon cavity, which is home to a host of microbes called the gut microbiome. Iron plays an important role in the growth of intestinal micro-organisms because it plays an important role as a ferritin cofactor in redox reactions, metabolic pathways and electron transport chains of microorganisms. Therefore, the content of iron ions in the colonic lumen will affect the composition, growth and living status of intestinal microbes, and conversely, the changes of intestinal microbes will also affect the health status of the host [64]. A growing number of studies have shown that the gastrointestinal tract and the central nervous system interact through the gut-brain axis, including neuronal, immune and metabolite-mediated pathways. Preclinical and clinical studies have shown that gut microbiome plays a key role in the gut-brain interaction, and that disturbances in the composition of gut microbiota are associated with the pathogenesis of neurological diseases, especially the neurodegenerative diseases [65]. Maternal immune activation (MIA) increases the risk of autism spectrum disorder (ASD) in offspring. Dysregulation of microorganisms is associated with ASD symptoms. In lipopolysaccharide (LIP) -induced MIA progenies, MIA progenies exhibited an abnormal brain-gut-microbiome axis compared with that of the control progenies, which were characterized by social behavioral deficits, anxiety-like and repetitive behaviors, low myelination, and ASD-like microbiome [66]. Studies have shown a potential link between host microbiome (such as gut and oral bacteria), neuroinflammation, and dementia, which may be caused by bacterial invasion of the brain due to barrier leakage, toxin and inflammation factor production, or indirectly by modulating immune responses, and moreover, the composition of microbiota affected the deposition level of A $\beta$ in the cerebral cortex of APP/PS1 mice [67], suggesting a critical role of iron in these processes.

\section{Brain Iron Metabolism}

\subsection{Brain Iron Absorption}

The brain is composed of neurons and glia. Ferritin is also the main iron storage protein in neurons, and neuromelanin has been found to storeiron ions for a long time. In glial cells, astrocytes and microglia synthesize L-ferritin to store iron ions, and L- and $\mathrm{H}$-ferritin are expressed in oligodendrocytes [68]. Cells in the CNS are not in direct contact with nutrients, including iron ions. The blood-brain barrier (BBB) and blood-brain spinal cord barrier (BBSCB) separate the CNS from the system circulation. BBB is a special structure, which is composed of auxiliary feet of capillary endothelial cells, peripheral skin cells and astrocytes, and it strictly regulates the substances entering the CNS [69,70]. 
The hydrophobic BBB prevents the hydrophilic holo-TF from entering the nervous system. Holo-TF must pass across the BBB through the brain capillary endothelial cells. HoloTF in the blood circulation binds to the TF receptor TfR1 on the luminal surface of the brain capillary endothelial cells and enters the cells. The FPN on the abluminal surface transports ferrous iron out of the capillary endothelial cells, where $\mathrm{Fe}^{2+}$ are oxidized to $\mathrm{Fe}^{3+}$ by ceruloplasmin $(\mathrm{CP})[71,72]$. CP is expressed in astrocytes and promotes the transport of FPN-exported ferrous iron [24,73]. The binding of iron ions into intercellular fluid and cerebrospinal fluid is secreted by nerve cells, especially TF, synthesized and secreted by oligodendrocytes, and choroid plexus cells, which diffuse through brain parenchymal tissue and bind to the TfR1 receptor on the surface of nerve cell membranes. After releasing iron ions, apo-TF enters the blood circulation through arachnoid villi [71,74]. FPN is regulated by hepcidin in the system, although the source of hepcidin in the brain is unknown. It may enter the brain across the BBB for iron metabolism regulation [68].

\subsection{Brain Iron Regulation}

The regulation of brain iron homeostasis at the cellular level involves IRPs regulating the expression of related proteins $[9,75,76]$. The decrease in the IRP2 expression level will lead to the imbalance of brain iron, but it has little effect on myelin iron. Mutations in genes controlling brain iron homeostasis will lead to the disorder of brain iron metabolism and affect the synthesis of myelin. It is unclear whether hepcidin plays a key role in the mediation of brain iron metabolism; whether hepcidin is synthesized in the brain or passes through the BBB after its synthesis in the liver has not been revealed. Recent results show that inflammation activates microglia and promotes the release of hepcidin by astrocytes in the model of signal cascade between inflammatory cells; this signal prevents the release of iron ions in neurons and eventually leads to neuronal death. At the same time, it will also lead to the release of anti-inflammatory and pro-inflammatory factors. Normal human microglia are not activated, and there is no intercellular signal cascade [36,72,77].

\subsection{Brain Iron Accumulation and Toxicity}

Iron ions accumulate in the brain with age $[9,78,79]$. Iron ions mainly bind to ferritin protein and substantia nigra [80-82]. The accumulation of iron ions can induce neurotoxicity through different mechanisms. The excessive accumulation of iron ions will increase the permeability of the BBB, induce inflammation, affect the redistribution of iron ions in the brain, and then change brain iron metabolism [47]. Iron ions can act as both electron acceptors and electron donors; therefore, when iron ions accumulate in the brain, they will produce reactive oxygen free radicals through Fenton and Haber-Weiss chemical reactions $[41,83,84]$. Free radicals are highly active substances, which may promote protein oxidation, membrane lipid peroxidation and nucleic acid modification. When the levels of ROS exceed the antioxidant capacity of organelles, this will induce oxidative stress and damage neurons $[38,85,86]$, leading to tissue degradation in severe cases.

$$
\begin{gathered}
\mathrm{Fe}^{2+}+\mathrm{H}_{2} \mathrm{O}_{2} \rightarrow \mathrm{Fe}^{3+}+\mathrm{OH}^{\bullet}+\mathrm{OH}^{-} \text {(Fenton) } \\
\mathrm{Fe}^{3+}+\mathrm{O}_{2}^{\bullet-} \rightarrow \mathrm{Fe}^{2+}+\mathrm{O}_{2} \\
\mathrm{O}_{2}^{\bullet-}+\mathrm{H}_{2} \mathrm{O}_{2} \rightarrow \mathrm{O}_{2}+\mathrm{OH}^{\bullet}+\mathrm{OH}^{-} \text {(Haber-Weiss) }
\end{gathered}
$$

\section{Iron Metabolism and AD}

\subsection{Effect of Iron Metabolism Disorder on $A D$}

$\mathrm{AD}$ is the most common cause of dementia, which is characterized by impaired cognitive function and decreased ability of learning, memory and reasoning [24,87]. It was originally described by Dr. Alois Alzheimer, a German doctor. Patients with this kind of disease exhibit strange behavioral symptoms, memory loss and motor loss. Its histopathological characteristics are amyloid plaques deposited outside the cells, and the excessive phosphorylation of tau protein related to the cytoskeleton which forms 
neurofibrillary tangles in the cells [88-90]. With the increase in age, iron ions in the brain tend to accumulate, especially in the cortex, globus pallidus, red nucleus, dentate nucleus and substantia nigra; however, the related molecular mechanisms are not clear at present $[9,74,79]$. The emerging evidence shows that iron with high redox activity is related to the deposition of amyloid plaques and the formation of nerve fiber tangles, suggesting it may be one of the main causes of AD [91-94].

The postmortem brain anatomy of AD patients showed that there was more $A \beta$ deposition and neurofibrillary tangles in the hippocampal region of the patients [95-97]. Moreover, by detecting the level of antioxidant protein in the hippocampus and amygdala, the level of oxidative stress in these two regions was found to be much higher than other regions. Moreover, the oxidative stress caused by iron accumulation will enhance the activity of IRP1, resulting in the enhancement of iron absorption through TfR1 and the increase in intracellular free iron level by reducing the concentration of ferritin- $\mathrm{H}$ and ferritin-L, which further enhances intracellular oxidative stress [93,98]. Based on magnetic resonance imaging (MRI) technology [99], it was found that iron accumulation may further lead to the deposition of $A \beta$ amyloid and the formation of neurofibrillary tangles in the brain of $\mathrm{AD}$ patients. Considerable studies have shown that iron metabolism disorder can affect $A \beta$ misfolding and tau hyperphosphorylation, and the resultant oxidative stress and metal toxicity of iron ions may lead to AD [100-103].

Even more evidence supports a key role of ROS and RNS (reactive nitrogen species) in leading to $\mathrm{AD}$, which are toxic and related to the formation of oxidative stress in the brain of AD patients [104]. The oxidative stress was more obvious with the increase in iron concentration, and the oxidation of protein, lipid and DNA in A $\beta$ aggregation area was more significant $[105,106]$. The free radicals produced at regions of $A \beta$ aggregation will destroy the adjacent neurons, resulting in a decline in cognitive and memory functions. The accumulation of tau protein in neurofibrillary tangles is also related to the induction of heme oxygenase-1 (HO-1). Overexpression of HO-1 can lead to the increase in iron content and accumulation of tau proteins in the mouse brain. In AD patients or patients with slight cognitive impairment, the concentration of HO- 1 in the hippocampus and frontal cortex increased $[86,107,108]$. Increased levels of iron-bound melanin transfer protein were detected in the serum of AD patients, indicating that there may be abnormal binding of iron in the brain of $\mathrm{AD}$ patients. It was also found that iron ions accumulated in regions of $\mathrm{A} \beta$ deposition and neurofibrillary tangles formed by hyperphosphorylation of tau protein, and which were distributed in hippocampus, parietal cortex and motor cortex $[93,106,109-112]$. The $A \beta$ amyloid is a segment of amyloid precursor protein (APP) cleaved by secretory enzymes [113]. APP is a transmembrane protein mainly expressed in the nervous system. At present, the physiological function of APP is not fully understood, and it may play a role in brain development, memory and synaptic plasticity [114]. In nerve cells, the concentration of iron ions regulates expression of the APP gene. The mechanism is shown in Figure 4. There is a loop ring formed by 11 bases in the $5^{\prime}$-UTR region of APP mRNA, which is called IRE. IRPs combine with IRE to regulate the synthesis of APP. High concentrations of iron in cells will combine with IRP1 to form iron sulfur clusters; at the same time, high concentrations of iron will also induce conformational changes in the IRE region of APP mRNA, increasing the expression of APP. In contrast, when the cell iron concentration is at a low level, IRP1 will bind to IRE and the expression of APP will decrease $[97,106,115]$. Under the action of different secretory enzymes in nerve cells, APP can undergo two different cleaving pathways, including the amyloidosis pathway and non-amyloidosis pathway. In the normal physiological state, APP is cleaved through the non-amyloidosis pathway, in which APP is firstly cleaved by $\alpha$ secretory enzyme, producing a segment called sA $\beta \mathrm{PP} \alpha$; then, the fragments undergo $\beta$ and $\gamma$ secretase cleavage to form non-toxic fragments of $\mathrm{P} 3, \mathrm{~A} \beta_{16}$ and $\mathrm{A} \beta_{17-40 / 42}$, respectively. The high concentrations of iron in cells promote the cleaving of APP through amyloidosis pathway, in which APP undergoes $\beta$ and $\gamma$ secretases cleavage to form $A \beta_{1-40}$ and $A \beta_{1-42}$ fragments. The $A \beta_{1-42}$ fragment is precipitated by Ile 41 , and the three histidines at its $\mathrm{N}$-terminal 
can combine with $\mathrm{Fe}^{2+}$ to induce oxidative stress, resulting in $\mathrm{A} \beta_{1-42}$ damage to cells at deposition [93,106,109-111,115].

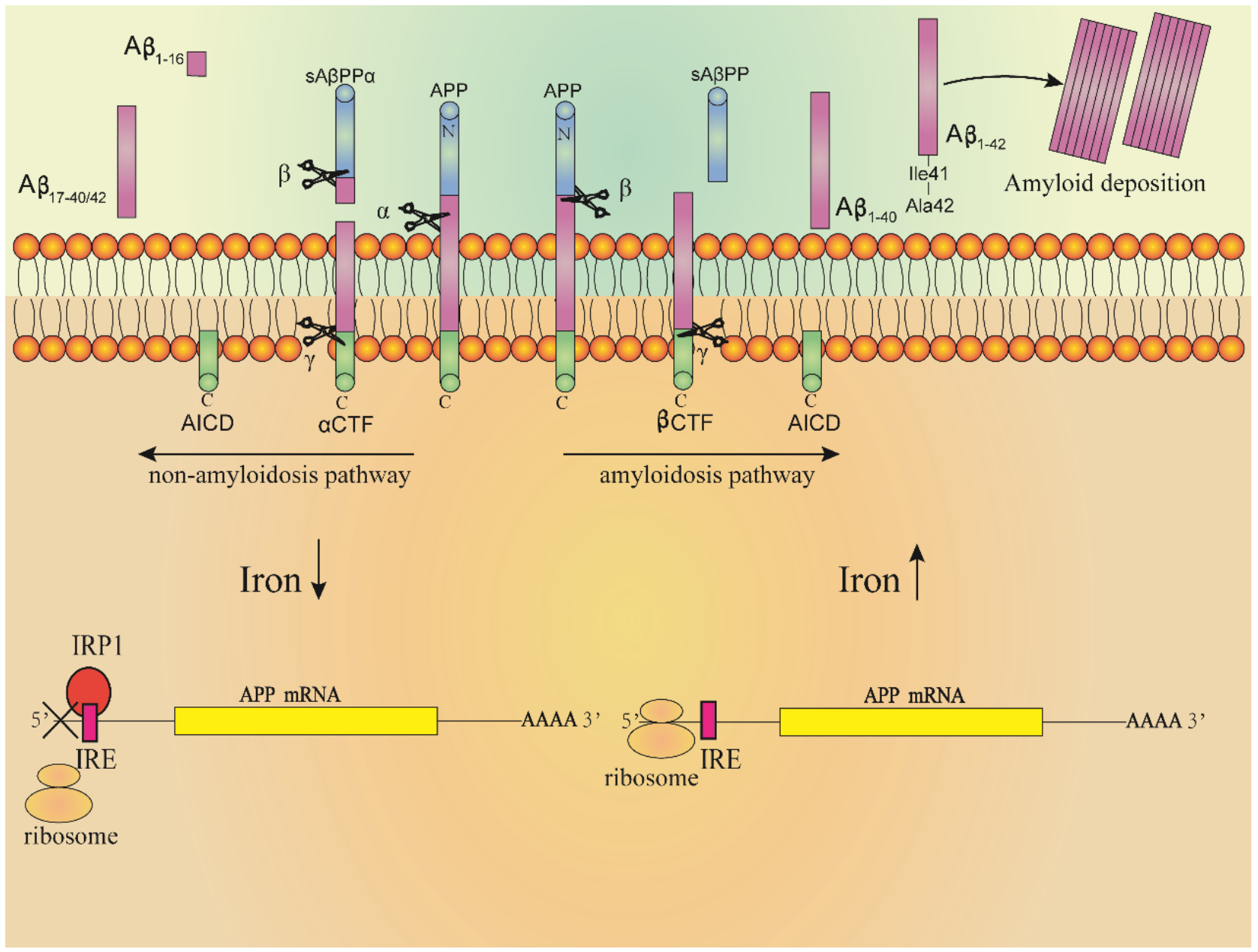

Figure 4. High concentrations of iron in neurons induce A $\beta$ formation. The $5^{\prime}$-UTR region of APP mRNA has an 11-base loop called IRE. The combination of IRPs and IRE regulates the synthesis of APP. The high concentration of iron in the cell will combine with IRP1 to form iron-sulfur clusters, and make IRP1 lose the ability to bind to IRE. At the same time, high concentrations of iron will also induce conformational changes in the IRE region of APP mRNA, which increases the expression of APP; in contrast, when the iron concentration in the cell is at a low level, IRP1 will bind to the IRE of APP mRNA, resulting in the decreased production of $A \beta_{42}$. A $\beta_{1-42}$ aggregates to form amyloid plaques.

In addition, the deposition of $A \beta_{1-42}$ can induce the hyperphosphorylation of tau protein, although the specific mechanism is not clear. At the same time, it can also lead to the disorder of energy metabolism, the activation of immune cells and the disorder of normal function of nerve cells, resulting in cell damage and death [50]. NFTs formed by the hyperphosphorylation of tau proteins and the combination of cytoskeleton mean that the cells are unable to maintain their normal structure. Many neurons in AD patients are affected by NFTs. A large number of NFTs were found in the hippocampus of patients with $\mathrm{AD}$, and the hippocampus participates in the processing of experience and precedes the storage of permanent memory. In the early stages of $\mathrm{AD}$, the clinical manifestations are the decline of learning ability, the ability to form new memory and the memory storage ability. At the same time, the basal forebrain, which provides the innervation activity of cholinergic neurons for the cortex, will also be affected, resulting in the reduction in cholinergic neurotransmitters. Generally, cholinergic enzyme inhibitors can be used to treat the reduction in cholinergic neurotransmitters. A Canadian butylcholinesterase inhibitor exhibited good performance for the treatment of AD symptoms. In clinical treatment, it 
has been shown that this drug is suitable for the improvement of mild and moderate AD symptoms [116].

\subsection{Relationship between Iron-Homeostasis-Related Proteins and AD}

Oxidative stress can lead to neuronal damage; it has been observed that the disorder of iron metabolism and the expressional change in iron regulatory proteins in the iron metabolism pathway could lead to the accumulation of iron ions in the brain and induce oxidative stress, resulting in the damage of neurons [107]. Many experimental results have showed that iron accumulation in the brain of AD patients is one of the sources of brain oxidative stress, and this has a close relationship with the disorder of brain iron metabolism and some key iron homeostasis regulators, such as ferritin protein, transferrin protein, FPN, etc. [100].

\subsubsection{Apolipoprotein $\mathrm{E}$ and $\mathrm{AD}$}

Apolipoprotein E (ApoE) is involved in the transport of cholesterol and other substances from the brain to the blood, including the discharge of $\mathrm{A} \beta$ protein from the brain to the blood. ApoE has three different conformations, which are encoded by ApoE2, ApoE3 and ApoE4 genes [117]. These three conformations are due to the differences in amino acid composition, resulting in differences in the structure, binding properties and multiple functions of lipoproteins. Among the three conformations, ApoE4 can lead to AD [18,118-122]. It can be seen from the extant literature that high concentrations of iron in cells will induce oxidative stress and cause damage to lipids, proteins and nucleic acids. Among them, lipid peroxidation will induce the production of 4-hydroxynonenal (4-HNE) molecules with high activity and neurotoxicity. It can combine with cysteine residues, lysine residues and histidine residues to reduce its damage to other molecules. Compared with ApoE2 and ApoE3, ApoE4 lacks cysteine amino acid and cannot clear HNE, resulting in the oxidative modification of proteins in neurons and neuronal death, increasing the risk of AD [123,124].

\subsubsection{Ferroptosis and AD}

Ferroptosis is an iron-dependent programmed cell death, which can lead to many diseases [125]. Ferroptosis was first described by Dixon in 2012, and is characterized by the accumulation of lipid reactive oxygen species. The experimental results show that GPX4 knockout mice exhibit neuronal necrosis, which will become more serious due to the lack of vitamin $\mathrm{E}$ (iron death inhibitor) in food. In contrast, inhibiting iron death can effectively improve the symptoms of AD. GPX4 is an anti-peroxidase that inhibits lipid peroxidation [101,126]. Moreover, lipid peroxidation products and 4-HNE in the AD brain have been significantly increased, indicating that ferroptosis will increase the risk of AD [127-129]. Iron induces oxidative stress, directly affecting lipids, DNA and proteins. Lipid peroxidation and iron metabolism disorder and accumulation in AD brain are also necessary conditions for ferroptosis [130]. In addition, iron ions interact with $A \beta$ and Tau to induce ROS, which also leads to ferroptosis [101,129].

\subsubsection{Iron Homeostasis Key Regulators and AD}

Through the utilization of Western blot technology, researchers have found that in comparison with ferritin protein in the normal brain, the expression levels of ferritin protein in the brains of AD patients were increased significantly, including L-ferritin and H-ferritin proteins [36]. The ELISA results showed that the concentrations of $\mathrm{H}$-ferritin and L-ferritin in the hippocampus of AD patients were three times higher than those in normal human brains. Moreover, the increases in H-ferritin and L-ferritin protein concentrations were not consistent with the increase in iron concentration, which was about $50 \%$ of the increase in iron concentration. Compared with the normal brain, the expression levels of ferrous oxidase CP increased significantly [131]. Results obtained from immunohistochemical experiments showed that the expression levels of transferrin proteins in the AD brains were also found to be increased compared with those in the normal brain [100]. 
However, by using Weston blot technology, it was found that the expression levels of DMT1 and FPN decreased in the AD brains compared with those of normal human brains. Due to the abnormal expression of genes related to iron metabolism, iron accumulates in $\mathrm{AD}$ brain and induces oxidative stress, which may damage brain neurons $[36,131]$.

\subsubsection{Furin and $\mathrm{AD}$}

Furin is associated with iron and $A \beta$ metabolism [132]. Low concentrations of iron enhance furin enzyme activity, whereas high concentrations of iron reduce furin enzyme activity. Furin can enhance the activity of $\alpha$ secretory enzymes, and high concentrations of iron in cells reduce furin enzyme activity, leading to the amyloidosis pathway of APP cleaving. Recent experimental results also showed that the expression levels of furin mRNA in the brain of AD patients are lower than those of normal human brains $[9,110,133]$.

\section{Strategies for Treating AD}

\subsection{Iron Chelation in the Treatment of $A D$}

Iron chelation strategy is the most direct method for limiting and redistributing iron in the system. At present, the most commonly used chelating agents are deferoxamine, deferrone and ferrite $[2,134,135]$. Deferoxamine is a chelating agent, recently found to exhibit good clinical manifestations. Although these chelating agents can improve the symptoms of $\mathrm{AD}$ caused by iron excess to a certain extent, they can also have toxic effects on the human body, such as allergic reactions, liver and kidney failure, etc. [1,136].

\subsection{Regulating Iron Metabolism Pathway Proteins to Improve AD Symptoms}

Fursultiamine is a small molecular substance called thiamine tetrahydrofuran disulfide, which can bind to cys 326 amino acid residues of brain FPN and protect hepcidin from the endocytosis of FPN, thus improving the efflux of brain iron through this ferrous transporter. However, fursultiamine has limited functions in the body, because it can be quickly converted to ammonium sulfate, resulting in reduced iron contents in the body [137].

The anti-ferroportin antibody ly2928057 was successfully tested in vitro, and it has also been tested for its potential to effectively reduce iron concentrations in vivo by interfering with the potential regulatory mechanism of hepcidin. The specific mechanism is to regulate the BMP6 (bone morphogenetic protein 6)-SMAD signal pathway and prevent the binding of BMP6 to its receptor BMP6R $[1,138]$. Another way is to block the phosphorylation of SAMD with doxomorphine, so as to reduce the production of hepcidin induced by BMP6R [139]. The body has its own regulatory mechanism; therefore, the treatment of FPN or hepcidin interference is a great challenge, which is not conducive to long-term treatment.

Similar to glutathione peroxidase, ebselene, a drug containing selenium, also exhibits antioxidant effects. This drug can inhibit the absorption of iron ions through DMT1; however, it can cause cardiomyopathy [140]. Recent studies have shown that pyrazole derivatives and benzyl isothiourea have inhibitory effects on DMT1 both in vitro and in vivo [141].

\subsection{Antioxidant Therapy Improves AD Symptoms}

Brain iron excess induces oxidative stress through Fenton chemical reactions, which cause damage to protein, lipid and DNA [7], and lead to ryanodine-receptor-mediated calcium release under the stress, resulting in neurotoxicity [105]. Small molecular substances have been designed for ROS scavenging at fixed sites. These kinds of antioxidants enter the mitochondrial matrix driven by the mitochondrial intimal potential to scavenge active free radicals in the matrix [142]. In addition, antioxidants in food, such as tea polyphenols, can effectively improve AD symptoms through scavenging oxygen free radicals, chelating iron ions and their anti-inflammatory effects [143-145]. Other native neuroprotective compounds or species include resveratrol, curcumin, pinocembrin, caffeine, the combination of Panax ginseng, ginkgo biloba, crocus sativus [146-150]. The anti-inflammatory and 
antioxidant properties of catechins in tea have been reported in vivo and in vitro, with potential for the prevention of AD symptoms [151].

Acetylcholinesterase inhibitors (AChEIs) have also been found to exhibit antioxidant effects. In 2010, Sinem et al. showed that ACHEIs can reduce the levels of lipid oxidation, blood markers and nitric oxide in AD patients [152]. ACHEI is the main drug for the treatment of AD, but it also has certain limitations [153].

\section{Conclusions and Prospect}

Iron is a rich metal element in the earth's crust. The unique redox properties of iron allow for efficient electron transfer, which is beneficial to many diverse biological reactions [154]. However, when iron metabolism in the body is unbalanced, such reactive properties of iron may also promote the generation of ROS, which will lead to the excessive accumulation of iron ions in the body $[155,156]$. As a result, there are fine regulatory mechanisms for iron absorption, storage and distribution in organisms. The excessive accumulation of iron induces oxidative stress reactions, which, in large doses, can be damaging to intracellular systems, including the tissues and organs of the body. Moreover, iron plays an important role in the formation of a myelin sheath in the brain and aerobic respiration in mitochondria. When brain iron metabolism is disordered, iron will be enriched in different regions of the brain, and the enriched iron will cause oxidative stress, mediate APP undergoing the amyloidosis pathway, and finally lead to the development of $\mathrm{AD}$. In $\mathrm{AD}$, oxidative stress caused by brain iron accumulation promotes the deposition of amyloid protein and the hyperphosphorylation of tau, which causes damage to neurons, resulting in declines in motor, cognitive and memory functions, etc. [133]. Although using iron-chelating strategies has achieved some positive results for improving the symptoms of $\mathrm{AD}$, there is still much research needed in order to translate the research into practice for the clinical treatment of $\mathrm{AD}$.

Nevertheless, there have been few studies on iron-reducing strategies in AD patients through genetic methods, and excessive emphasis has been put on the amyloid-reducing strategies, which have been disappointing thus far. Given that more and more ironchelating compounds have potential disease-improving effects, as well as the availability of biomarkers of iron load in MRI and cerebrospinal fluid, there is considerable room for exploring this type of treatment to avoid its side effects as far as possible. In addition, genetic studies on the regulation of some key genes in iron homeostasis in model animals have shown potential for more effective and precise treatment [14,157].

Furthermore, $\mathrm{AD}$ is characterized by the progressive dysfunction and death of thecortical and hippocampal neurons; the main hypothetical mechanisms are the hyperphos-phorylation of tau protein to form NFTs and the deposition of $A \beta$ protein to form SPs [158,159]. However, a large number of clinical trials of drugs based on these two hypotheses all over the world have ended in failure; there is currently no effective treatment method. In addition, these two assumptions are facing increasing challenges $[160,161]$. In fact, the involvement of iron in the pathogenesis of AD has been widely accepted. Iron not only aggravates the accumulation of toxic $A \beta$ and hyperphosphorylated tau, but also directly induces neuronal oxidative damage [162]. Considering the particularity and importance of iron role in the process of ferroptosis, it is essential to uncover how does ferroptosis play in the molecular pathophysiology of AD in the future research, which may provide new insights into the disease $[163,164]$ and new ideas for the treatment [101]. Combing with the recent finding of a potential link among iron, host microbiome and $\mathrm{AD}$, therefore, by deeply studying the mechanism of iron metabolism in the body and brain, it is expected to find new effective targets and therapeutic measures to improve or cure the disease.

Author Contributions: Concept and design: M.L. Writing, review of manuscript: Y.P. and M.L. Revision of manuscript: M.L., Y.P. and X.C. Display item design: Y.P. All authors have read and agreed to the published version of the manuscript. 
Funding: This work was supported by the Fundamental Research Funds for the Central Universities, Beijing Municipal Natural Science Foundation (7202129), the Class B Breeding Program of Special Projects for Leading Science and Technology of the Chinese Academy of Sciences (XDPB16), the National Natural Science Foundation of China (31571042), the Key Basic Research Project of Applied Basic Research Program of Hebei Province (18966315D), and One Hundred Outstanding Creative Talents Support Program of Hebei (BR2-218).

Institutional Review Board Statement: Not applicable.

Informed Consent Statement: Not applicable.

Data Availability Statement: Not applicable.

Conflicts of Interest: The authors declare no conflict of interest.

$\begin{array}{ll}\text { Abbreviations } \\ \text { AD } & \text { Alzheimer's disease } \\ \text { CNS } & \text { central nervous system } \\ \text { ROS } & \text { reactive oxygen species } \\ \text { NFTs } & \text { neurofibrillary tangles } \\ \text { DCYTB } & \text { duodenal cytochrome-b-like protein } \\ \text { DMT1 } & \text { divalent metal transporter1 } \\ \text { FPN } & \text { ferroportin } \\ \text { TF } & \text { transferrin } \\ \text { TfR1 } & \text { transferrin receptor 1 } \\ \text { STEAP } & \text { six-transmembrane epithelial antigen of prostate } \\ \text { IRPs } & \text { iron regulatory proteins } \\ \text { IRE } & \text { iron regulatory element } \\ \text { BBB } & \text { blood-brain barrier } \\ \text { BBSCB } & \text { blood-brain spinal cord barrier } \\ \text { CP } & \text { ceruloplasmin } \\ \text { MRI } & \text { magnetic resonance imaging } \\ \text { RNS } & \text { reactive nitrogen species } \\ \text { HO-1 } & \text { heme oxygenase-1 } \\ \text { APP } & \text { amyloid precursor protein } \\ \text { ApoE } & \text { apolipoprotein E } \\ \text { 4-HNE } & \text { 4-hydroxynonenal } \\ \text { BMP6 } & \text { bone morphogenetic protein } 6 \\ \text { AChEI } & \text { acetylcholinesterase inhibitor } \\ & \end{array}$

\section{References}

1. Galaris, D.; Barbouti, A.; Pantopoulos, K. Iron homeostasis and oxidative stress: An intimate relationship. Biochim. Biophys. Acta Mol. Cell Res. 2019, 1866, 118535. [CrossRef] [PubMed]

2. Evstatiev, R.; Gasche, C. Iron sensing and signalling. Gut 2012, 61, 933-952. [CrossRef] [PubMed]

3. Conway, D.; Henderson, M.A. Iron metabolism. Anaesth. Intensive Care Med. 2019, 20, 175-177. [CrossRef]

4. Lane, D.J.R.; Ayton, S.; Bush, A.I. Iron and Alzheimer's Disease: An Update on Emerging Mechanisms. J. Alzheimers Dis. 2018, 64, S379-S395. [CrossRef] [PubMed]

5. Ashraf, A.; Clark, M.; So, P.W. The Aging of Iron Man. Front. Aging Neurosci. 2018, 10, 65. [CrossRef] [PubMed]

6. Jomova, K.; Valko, M. Advances in metal-induced oxidative stress and human disease. Toxicology 2011, 283, 65-87. [CrossRef]

7. Papanikolaou, G.; Pantopoulos, K. Iron metabolism and toxicity. Toxicol. Appl. Pharmacol. 2005, 202, 199-211. [CrossRef]

8. Ward, R.J.; Zucca, F.A.; Duyn, J.H.; Crichton, R.R.; Zecca, L. The role of iron in brain ageing and neurodegenerative disorders. Lancet Neurol. 2014, 13, 1045-1060. [CrossRef]

9. Cassidy, L.; Fernandez, F.; Johnson, J.B.; Naiker, M.; Owoola, A.G.; Broszczak, D.A. Oxidative stress in alzheimer's disease: A review on emergent natural polyphenolic therapeutics. Complement. Ther. Med. 2020, 49, 102294. [CrossRef]

10. Oboudiyat, C.; Glazer, H.; Seifan, A.; Greer, C.; Isaacson, R.S. Alzheimer's disease. Semin. Neurol. 2013, 33, 313-329. [CrossRef]

11. Jalili-Baleh, L.; Babaei, E.; Abdpour, S.; Nasir Abbas Bukhari, S.; Foroumadi, A.; Ramazani, A.; Sharifzadeh, M.; Abdollahi, M.; Khoobi, M. A review on flavonoid-based scaffolds as multi-target-directed ligands (MTDLs) for Alzheimer's disease. Eur. J. Med. Chem. 2018, 152, 570-589. [CrossRef]

12. Brody, H. Alzheimer's disease. Nature 2011, 475, S1. [CrossRef] [PubMed] 
13. Power, R.; Prado-Cabrero, A.; Mulcahy, R.; Howard, A.; Nolan, J.M. The Role of Nutrition for the Aging Population: Implications for Cognition and Alzheimer's Disease. Annu. Rev. Food Sci. Technol. 2019, 10, 619-639. [CrossRef] [PubMed]

14. Ranasinghe, K.G.; Cha, J.; Iaccarino, L.; Hinkley, L.B.; Beagle, A.J.; Pham, J.; Jagust, W.J.; Miller, B.L.; Rankin, K.P.; Rabinovici, G.D.; et al. Neurophysiological signatures in Alzheimer's disease are distinctly associated with TAU, amyloid-beta accumulation, and cognitive decline. Sci. Transl. Med. 2020, 12, 534. [CrossRef]

15. Briggs, R.; Kennelly, S.P.; O'Neill, D. Drug treatments in Alzheimer's disease. Clin. Med. 2016, 16, 247-253. [CrossRef] [PubMed]

16. Mandel, S.; Amit, T.; Bar-Am, O.; Youdim, M.B. Iron dysregulation in Alzheimer's disease: Multimodal brain permeable iron chelating drugs, possessing neuroprotective-neurorescue and amyloid precursor protein-processing regulatory activities as therapeutic agents. Prog. Neurobiol. 2007, 82, 348-360. [CrossRef] [PubMed]

17. Belaidi, A.A.; Bush, A.I. Iron neurochemistry in Alzheimer's disease and Parkinson's disease: Targets for therapeutics. J. Neurochem. 2016, 139 (Suppl. S1), 179-197. [CrossRef]

18. Bush, A.I. The metallobiology of Alzheimer's disease. Trends Neurosci. 2003, 26, 207-214. [CrossRef]

19. Andrews, N.C. Iron Metabolism, in Principles of Molecular Medicine; Runge, M.S., Patterson, C., Eds.; Humana Press: Totowa, NJ, USA, 2006; pp. 848-853.

20. Ganz, T. Systemic iron homeostasis. Physiol. Rev. 2013, 93, 1721-1741. [CrossRef]

21. Arosio, P.; Levi, S. Cytosolic and mitochondrial ferritins in the regulation of cellular iron homeostasis and oxidative damage. Biochim. Biophys. Acta 2010, 1800, 783-792. [CrossRef]

22. Theil, E.C. Ferritin: At the crossroads of iron and oxygen metabolism. J. Nutr. 2003, 133 (Suppl. S1), 1549S-1553S. [CrossRef] [PubMed]

23. Oshiro, S.; Morioka, M.S.; Kikuchi, M. Dysregulation of iron metabolism in Alzheimer's disease, Parkinson's disease, and amyotrophic lateral sclerosis. Adv. Pharmacol. Sci. 2011, 2011, 378278. [CrossRef]

24. Nemeth, E.; Tuttle, M.S.; Powelson, J.; Vaughn, M.B.; Donovan, A.; Ward, D.M.; Ganz, T.; Kaplan, J. Hepcidin regulates cellular iron efflux by binding to ferroportin and inducing its internalization. Science 2004, 306, 2090-2093. [CrossRef]

25. Ganz, T. Cellular iron: Ferroportin is the only way out. Cell Metab. 2005, 1, 155-157. [CrossRef] [PubMed]

26. Mayle, K.M.; Le, A.M.; Kamei, D.T. The intracellular trafficking pathway of transferrin. Biochim. Biophys. Acta 2012, 1820, $264-281$. [CrossRef] [PubMed]

27. Lane, D.J.; Merlot, A.M.; Huang, M.L.; Bae, D.H.; Jansson, P.J.; Sahni, S.; Kalinowski, D.S.; Richardson, D.R. Cellular iron uptake, trafficking and metabolism: Key molecules and mechanisms and their roles in disease. Biochim. Biophys. Acta 2015, 1853, 1130-1144. [CrossRef]

28. Zhou, Z.D.; Tan, E.K. Iron regulatory protein (IRP)-iron responsive element (IRE) signaling pathway in human neurodegenerative diseases. Mol. Neurodegener. 2017, 12, 75. [CrossRef] [PubMed]

29. Hentze, M.W.; Muckenthaler, M.U.; Galy, B.; Camaschella, C. Two to tango: Regulation of Mammalian iron metabolism. Cell 2010, 142, 24-38. [CrossRef]

30. Knutson, M.D. Steap proteins: Implications for iron and copper metabolism. Nutr. Rev. 2007, 65, 335-340.

31. Sendamarai, A.K.; Ohgami, R.S.; Fleming, M.D.; Lawrence, C.M. Structure of the membrane proximal oxidoreductase domain of human Steap3, the dominant ferrireductase of the erythroid transferrin cycle. Proc. Natl. Acad. Sci. USA 2008, 105, 7410-7415. [CrossRef]

32. Crielaard, B.J.; Lammers, T.; Rivella, S. Targeting iron metabolism in drug discovery and delivery. Nat. Rev. Drug Discov. 2017, 16, 400-423. [CrossRef] [PubMed]

33. Upadhyay, M.; Agarwal, S. Ironing the mitochondria: Relevance to its dynamics. Mitochondrion 2020, 50, 82-87. [CrossRef]

34. Ganz, T.; Nemeth, E. Hepcidin and iron homeostasis. Biochim. Biophys. Acta 2012, 1823, 1434-1443. [CrossRef]

35. Cohen, L.A.; Gutierrez, L.; Weiss, A.; Leichtmann-Bardoogo, Y.; Zhang, D.L.; Crooks, D.R.; Sougrat, R.; Morgenstern, A.; Galy, B.; Hentze, M.W.; et al. Serum ferritin is derived primarily from macrophages through a nonclassical secretory pathway. Blood 2010, 116, 1574-1584. [CrossRef] [PubMed]

36. Zecca, L.; Youdim, M.B.; Riederer, P.; Connor, J.R.; Crichton, R.R. Iron, brain ageing and neurodegenerative disorders. Nat. Rev. Neurosci. 2004, 5, 863-873. [CrossRef]

37. Liu, Z.; Shen, H.C.; Lian, T.H.; Mao, L.; Tang, S.X.; Sun, L.; Huang, X.Y.; Guo, P.; Cao, C.J.; Yu, S.Y.; et al. Iron deposition in substantia nigra: Abnormal iron metabolism, neuroinflammatory mechanism and clinical relevance. Sci. Rep. 2017, 7, 14973. [CrossRef] [PubMed]

38. Meneghini, R. Iron Homeostasis, Oxidative Stress, and DNA Damage. Free. Radic. Biol. Med. 1997, 23, 783-792. [CrossRef]

39. Andrews, N.C. Molecular control of iron metabolism. Best Pract. Res. Clin. Haematol. 2005, 18, 159-169. [CrossRef] [PubMed]

40. Patel, S.J.; Frey, A.G.; Palenchar, D.J.; Achar, S.; Bullough, K.Z.; Vashisht, A.; Wohlschlegel, J.A.; Philpott, C.C. A PCBP1-BolA2 chaperone complex delivers iron for cytosolic [2Fe-2S] cluster assembly. Nat. Chem. Biol. 2019, 15, 872-881. [CrossRef] [PubMed]

41. Valko, M.; Leibfritz, D.; Moncol, J.; Cronin, M.T.; Mazur, M.; Telser, J. Free radicals and antioxidants in normal physiological functions and human disease. Int. J. Biochem. Cell Biol. 2007, 39, 44-84. [CrossRef]

42. Rishi, G.; Subramaniam, V.N. The liver in regulation of iron homeostasis. Am. J. Physiol. Gastrointest. Liver Physiol. 2017, 313, G157-G165. [CrossRef] [PubMed]

43. van Swelm, R.P.L.; Wetzels, J.F.M.; Swinkels, D.W. The multifaceted role of iron in renal health and disease. Nat. Rev. Nephrol. 2020, 16, 77-98. [CrossRef] 
44. Stankiewicz, J.M.; Neema, M.; Ceccarelli, A. Iron and multiple sclerosis. Neurobiol. Aging 2014, 35 (Suppl. S2), S51-S58. [CrossRef] [PubMed]

45. Leipuviene, R.; Theil, E.C. The family of iron responsive RNA structures regulated by changes in cellular iron and oxygen. Cell Mol. Life Sci. 2007, 64, 2945-2955. [CrossRef] [PubMed]

46. Pantopoulos, K.; Porwal, S.K.; Tartakoff, A.; Devireddy, L. Mechanisms of mammalian iron homeostasis. Biochemistry 2012, 51, 5705-5724. [CrossRef]

47. Sousa, L.; Oliveira, M.M.; Pessôa, M.T.C.; Barbosa, L.A. Iron overload: Effects on cellular biochemistry. Clin. Chim. Acta 2020, 504, 180-189. [CrossRef]

48. Pantopoulos, K. Iron metabolism and the IRE/IRP regulatory system: An update. Ann. N. Y. Acad. Sci. 2004, 1012, 1-13. [CrossRef]

49. Hin, N.; Newman, M.; Pederson, S.; Lardelli, M. Iron Responsive Element (IRE)-mediated responses to iron dyshomeostasis in Alzheimer's disease. bioRxiv 2021. [CrossRef]

50. Everett, J.; Céspedes, E.; Shelford, L.R.; Exley, C.; Collingwood, J.F.; Dobson, J.; van der Laan, G.; Jenkins, C.A.; Arenholz, E.; Telling, N.D. Ferrous iron formation following the co-aggregation of ferric iron and the Alzheimer's disease peptide beta-amyloid (1-42). J. R. Soc. Interface 2014, 11, 20140165. [CrossRef]

51. Kuhn, L.C. Iron regulatory proteins and their role in controlling iron metabolism. Metallomics 2015, 7, 232-243. [CrossRef]

52. Thomson, A.M.; Rogers, J.T.; Leedman, P.J. Iron-regulatory proteins, iron-responsive elements and ferritin mRNA translation. Int. J. Biochem. Cell Biol. 1999, 31, 1139-1152. [CrossRef]

53. Rouault, T.A. The role of iron regulatory proteins in mammalian iron homeostasis and disease. Nat. Chem. Biol. 2006, 2, 406-414. [CrossRef] [PubMed]

54. Wang, L.; Liu, X.; You, L.H.; Ci, Y.Z.; Chang, S.; Yu, P.; Gao, G.; Chang, Y.Z. Hepcidin and iron regulatory proteins coordinately regulate ferroportin 1 expression in the brain of mice. J. Cell. Physiol. 2019, 234, 7600-7607. [CrossRef]

55. Ganz, T. Hepcidin, a key regulator of iron metabolism and mediator of anemia of inflammation. Blood 2003, 102, 783-788. [CrossRef]

56. Knutson, M.D. Iron-sensing proteins that regulate hepcidin and enteric iron absorption. Annu. Rev. Nutr. 2010, 30, 149-171. [CrossRef]

57. Oates, P.S. The role of hepcidin and ferroportin in iron absorption. Histol. Histopathol. 2007, 22, 791-804. [PubMed]

58. Hunter, H.N.; Fulton, D.B.; Ganz, T.; Vogel, H.J. The solution structure of human hepcidin, a peptide hormone with antimicrobial activity that is involved in iron uptake and hereditary hemochromatosis. J. Biol. Chem. 2002, 277, 37597-37603. [CrossRef] [PubMed]

59. Qiao, B.; Sugianto, P.; Fung, E.; Del-Castillo-Rueda, A.; Moran-Jimenez, M.J.; Ganz, T.; Nemeth, E. Hepcidin-induced endocytosis of ferroportin is dependent on ferroportin ubiquitination. Cell Metab. 2012, 15, 918-924. [CrossRef] [PubMed]

60. Liu, X.B.; Nguyen, N.B.; Marquess, K.D.; Yang, F.; Haile, D.J. Regulation of hepcidin and ferroportin expression by lipopolysaccharide in splenic macrophages. Blood Cells Mol. Dis. 2005, 35, 47-56. [CrossRef] [PubMed]

61. Merle, U.; Fein, E.; Gehrke, S.G.; Stremmel, W.; Kulaksiz, H. The iron regulatory peptide hepcidin is expressed in the heart and regulated by hypoxia and inflammation. Endocrinology 2007, 148, 2663-2668. [CrossRef]

62. Nguyen, N.B.; Callaghan, K.D.; Ghio, A.J.; Haile, D.J.; Yang, F. Hepcidin expression and iron transport in alveolar macrophages. Am. J. Physiol. Lung Cell. Mol. Physiol. 2006, 291, L417-L425. [CrossRef]

63. Ganz, T.; Nemeth, E. Iron homeostasis in host defence and inflammation. Nat. Rev. Immunol. 2015, 15, 500-510. [CrossRef] [PubMed]

64. Seyoum, Y.; Baye, K.; Humblot, C. Iron homeostasis in host and gut bacteria-A complex interrelationship. Gut Microbes. 2021, 13, 1-19. [CrossRef]

65. Sun, P.; Sun, P.; Su, L.; Zhu, H.; Li, X.; Guo, Y.; Du, X.; Zhang, L.; Qin, C. Gut Microbiota Regulation and Their Implication in the Development of Neurodegenerative Disease. Microorganisms 2021, 9, 11. [CrossRef]

66. Lee, G.A.; Lin, Y.K.; Lai, J.H.; Lo, Y.C.; Yang, Y.S.H.; Ye, S.Y.; Lee, C.J.; Wang, C.C.; Chiang, Y.H.; Tseng, S.H. Maternal Immune Activation Causes Social Behavior Deficits and Hypomyelination in Male Rat Offspring with an Autism-Like Microbiota Profile. Brain Sci. 2021, 11, 8. [CrossRef] [PubMed]

67. Gonzalez-Sanmiguel, J.; Schuh, C.; Muñoz-Montesino, C.; Contreras-Kallens, P.; Aguayo, L.G.; Aguayo, S. Complex Interaction between Resident Microbiota and Misfolded Proteins: Role in Neuroinflammation and Neurodegeneration. Cells $2020,9,11$. [CrossRef]

68. Ndayisaba, A.; Kaindlstorfer, C.; Wenning, G.K. Iron in Neurodegeneration-Cause or Consequence? Front. Neurosci. 2019, 13, 180. [CrossRef] [PubMed]

69. Daneman, R.; Prat, A. The blood-brain barrier. Cold Spring Harb. Perspect. Biol. 2015, 7, a020412. [CrossRef]

70. Camandola, S.; Mattson, M.P. Brain metabolism in health, aging, and neurodegeneration. EMBO J. 2017, 36, 1474-1492. [CrossRef]

71. Rouault, T.A. Iron metabolism in the CNS: Implications for neurodegenerative diseases. Nat. Rev. Neurosci. 2013, 14, 551-564. [CrossRef]

72. Rouault, T.A.; Cooperman, S. Brain iron metabolism. Semin. Pediatr. Neurol. 2006, 13, 142-148. [CrossRef] [PubMed]

73. Patel, B.N.; Dunn, R.J.; Jeong, S.Y.; Zhu, Q.; Julien, J.P.; David, S. Ceruloplasmin Regulates Iron Levels in the CNS and Prevents Free Radical Injury. J. Neurosci. 2002, 22, 6578-6586. [CrossRef] [PubMed] 
74. Chiou, B.; Neal, E.H.; Bowman, A.B.; Lippmann, E.S.; Simpson, I.A.; Connor, J.R. Endothelial cells are critical regulators of iron transport in a model of the human blood-brain barrier. J. Cereb. Blood Flow Metab. 2019, 39, 2117-2131. [CrossRef]

75. Rouault, T.A. Post-transcriptional regulation of human iron metabolism by iron regulatory proteins. Blood Cells Mol. Dis. 2002, 29, 309-314. [CrossRef] [PubMed]

76. Meyron-Holtz, E.G.; Ghosh, M.C.; Iwai, K.; LaVaute, T.; Brazzolotto, X.; Berger, U.V.; Land, W.; Ollivierre-Wilson, H.; Grinberg, A.; Love, P.; et al. Genetic ablations of iron regulatory proteins 1 and 2 reveal why iron regulatory protein 2 dominates iron homeostasis. EMBO J. 2004, 23, 386-395. [CrossRef]

77. Gerlach, M.; Ben-Shachar, D.; Riederer, P.; Youdim, M.B. Altered brain metabolism of iron as a cause of neurodegenerative diseases? J. Neurochem. 1994, 63, 793-807. [CrossRef] [PubMed]

78. Ayton, S.; Lei, P. Nigral iron elevation is an invariable feature of Parkinson's disease and is a sufficient cause of neurodegeneration. BioMed Res. Int. 2014, 2014, 581256. [CrossRef] [PubMed]

79. Xiong, H.; Tuo, Q.Z.; Guo, Y.J.; Lei, P. Diagnostics and Treatments of Iron-Related CNS Diseases. Adv. Exp. Med. Biol. 2019, 1173, 179-194.

80. Zecca, L.; Pietra, R.; Goj, C.; Mecacci, C.; Radice, D.; Sabbioni, E. Iron and other metals in neuromelanin, substantia nigra, and putamen of human brain. J. Neurochem. 1994, 62, 1097-1101. [CrossRef]

81. Zecca, L.; Shima, T.; Stroppolo, A.; Goj, C.; Battiston, G.A.; Gerbasi, R.; Sarna, T.; Swartz, H.M. Interaction of neuromelanin and iron in substantia nigra and other areas of human brain. Neuroscience 1996, 73, 407-415. [CrossRef]

82. Zecca, L.; Gallorini, M.; Schünemann, V.; Trautwein, A.X.; Gerlach, M.; Riederer, P.; Vezzoni, P.; Tampellini, D. Iron, neuromelanin and ferritin content in the substantia nigra of normal subjects at different ages: Consequences for iron storage and neurodegenerative processes. J. Neurochem. 2001, 76, 1766-1773. [CrossRef]

83. Minotti, G.; Aust, S.D. Redox cycling of iron and lipid-peroxidation. Lipids 1992, 27, 219-226. [CrossRef]

84. Leitao, E.F.V.; Ventura, E.; de Souza, M.A.F.; Riveros, J.M.; do Monte, S.A. Spin-Forbidden Branching in the Mechanism of the Intrinsic Haber-Weiss Reaction. ChemistryOpen 2017, 6, 360-363. [CrossRef]

85. Farina, M.; Avila, D.S.; da Rocha, J.B.; Aschner, M. Metals, oxidative stress and neurodegeneration: A focus on iron, manganese and mercury. Neurochem. Int. 2013, 62, 575-594. [CrossRef]

86. Pham-Huy, L.A.; He, H.; Pham-Huy, C. Free radicals, antioxidants in disease and health. Int. J. Biomed. Sci. IJBS 2008, 4, 89. [PubMed]

87. Kent, S.A.; Spires-Jones, T.L.; Durrant, C.S. The physiological roles of tau and Abeta: Implications for Alzheimer's disease pathology and therapeutics. Acta Neuropathol. 2020, 140, 417-447. [CrossRef] [PubMed]

88. Skovronsky, D.M.; Lee, V.M.; Trojanowski, J.Q. Neurodegenerative diseases: New concepts of pathogenesis and their therapeutic implications. Annu. Rev. Pathol. 2006, 1, 151-170. [CrossRef] [PubMed]

89. McKhann, G.; Drachman, D.; Folstein, M.; Katzman, R.; Price, D.; Stadlan, E.M. Clinical diagnosis of Alzheimer's disease: Report of the NINCDS-ADRDA Work Group under the auspices of Department of Health and Human Services Task Force on Alzheimer's Disease. Neurology 1984, 34, 939-944. [CrossRef]

90. Frisoni, G.B.; Boccardi, M.; Barkhof, F.; Blennow, K.; Cappa, S.; Chiotis, K.; Démonet, J.F.; Garibotto, V.; Giannakopoulos, P.; Gietl, A.; et al. Strategic roadmap for an early diagnosis of Alzheimer's disease based on biomarkers. Lancet Neurol. 2017, 16, 661-676. [CrossRef]

91. Long, J.M.; Maloney, B.; Rogers, J.T.; Lahiri, D.K. Novel upregulation of amyloid-beta precursor protein (APP) by microRNA-346 via targeting of APP mRNA 5'-untranslated region: Implications in Alzheimer's disease. Mol. Psychiatry 2019, 24, 345-363. [CrossRef] [PubMed]

92. Smith, M.A.; Harris, P.L.; Sayre, L.M.; Perry, G. Iron accumulation in Alzheimer disease is a source of redox-generated free radicals. Proc. Natl. Acad. Sci. USA 1997, 94, 9866-9868. [CrossRef]

93. Altamura, S.; Muckenthaler, M.U. Iron toxicity in diseases of aging: Alzheimer's disease, Parkinson's disease and atherosclerosis. J. Alzheimers Dis. 2009, 16, 879-895. [CrossRef]

94. Hare, D.; Ayton, S.; Bush, A.; Lei, P. A delicate balance: Iron metabolism and diseases of the brain. Front. Aging Neurosci. 2013, 5, 34. [CrossRef]

95. Sengoku, R. Aging and Alzheimer's disease pathology. Neuropathology 2020, 40, 22-29. [CrossRef]

96. Ashrafian, H.; Zadeh, E.H.; Khan, R.H. Review on Alzheimer's disease: Inhibition of amyloid beta and tau tangle formation. Int. J. Biol. Macromol. 2021, 167, 382-394. [CrossRef]

97. Kozlov, S.; Afonin, A.; Evsyukov, I.; Bondarenko, A. Alzheimer's disease: As it was in the beginning. Rev. Neurosci. 2017, 28, 825-843. [CrossRef] [PubMed]

98. Cogswell, P.M.; Wiste, H.J.; Senjem, M.L.; Gunter, J.L.; Weigand, S.D.; Schwarz, C.G.; Arani, A.; Therneau, T.M.; Lowe, V.J.; Knopman, D.S.; et al. Associations of quantitative susceptibility mapping with Alzheimer's disease clinical and imaging markers. NeuroImage 2021, 224, 117433. [CrossRef] [PubMed]

99. Gong, N.J.; Dibb, R.; Bulk, M.; van der Weerd, L.; Liu, C. Imaging beta amyloid aggregation and iron accumulation in Alzheimer's disease using quantitative susceptibility mapping MRI. NeuroImage 2019, 191, 176-185. [CrossRef]

100. Connor, J.R.; Menzies, S.L.; St Martin, S.M.; Mufson, E.J. A histochemical study of iron, transferrin, and ferritin in Alzheimer's diseased brains. J. Neurosci. Res. 1992, 31, 75-83. [CrossRef] [PubMed] 
101. Yan, N.; Zhang, J. Iron Metabolism, Ferroptosis, and the Links With Alzheimer's Disease. Front. Neurosci. $2019,13,1443$. [CrossRef]

102. Spotorno, N.; Acosta-Cabronero, J.; Stomrud, E.; Lampinen, B.; Strandberg, O.T.; van Westen, D.; Hansson, O. Relationship between cortical iron and tau aggregation in Alzheimer's disease. Brain 2020, 143, 1341-1349. [CrossRef] [PubMed]

103. Borthakur, A.; Gur, T.; Wheaton, A.J.; Corbo, M.; Trojanowski, J.Q.; Lee, V.M.; Reddy, R. In vivo measurement of plaque burden in a mouse model of Alzheimer's disease. J. Magn. Reson. Imaging 2006, 24, 1011-1017. [CrossRef] [PubMed]

104. Agostinho, P.; Cunha, R.A.; Oliveira, C. Neuroinflammation, oxidative stress and the pathogenesis of Alzheimer's disease. Curr. Pharm. Des. 2010, 16, 2766-2778. [CrossRef] [PubMed]

105. Lee, D.G.; Kam, M.K.; Lee, S.R.; Lee, H.J.; Lee, D.S. Peroxiredoxin 5 deficiency exacerbates iron overload-induced neuronal death via ER-mediated mitochondrial fission in mouse hippocampus. Cell Death Dis. 2020, 11, 204. [CrossRef]

106. Bandyopadhyay, S.; Rogers, J.T. Alzheimer's disease therapeutics targeted to the control of amyloid precursor protein translation: Maintenance of brain iron homeostasis. Biochem. Pharmacol. 2014, 88, 486-494. [CrossRef]

107. Cheignon, C.; Tomas, M.; Bonnefont-Rousselot, D.; Faller, P.; Hureau, C.; Collin, F. Oxidative stress and the amyloid beta peptide in Alzheimer's disease. Redox Biol. 2018, 14, 450-464. [CrossRef]

108. Grundkeiqbal, I.; Fleming, J.; Tung, Y.C.; Lassmann, H.; Iqbal, K.; Joshi, J.G. Ferritin is a component of the neuritic (senile) plaque in Alzheimer dementia. Acta Neuropathol. 1990, 81, 105-110. [CrossRef] [PubMed]

109. Boopathi, S.; Kolandaivel, P. Fe ${ }^{2+}$ binding on amyloid beta-peptide promotes aggregation. Proteins 2016, 84, 1257-1274. [CrossRef]

110. Guillemot, J.; Canuel, M.; Essalmani, R.; Prat, A..; Seidah, N.G. Implication of the proprotein convertases in iron homeostasis: Proprotein convertase 7 sheds human transferrin receptor 1 and furin activates hepcidin. Hepatology 2013, 57, 2514-2524. [CrossRef]

111. Prasanna, G.; Jing, P. Self-assembly of N-terminal Alzheimer's beta-amyloid and its inhibition. Biochem. Biophys. Res. Commun. 2021, 534, 950-956. [CrossRef]

112. Rogers, J.T.; Bush, A.I.; Cho, H.H.; Smith, D.H.; Thomson, A.M.; Friedlich, A.L.; Lahiri, D.K.; Leedman, P.J.; Huang, X.; Cahill, C.M. Iron and the translation of the amyloid precursor protein (APP) and ferritin mRNAs: Riboregulation against neural oxidative damage in Alzheimer's disease. Biochem. Soc. Trans. 2008, 36 Pt 6, 1282-1287. [CrossRef] [PubMed]

113. Wilkins, H.M.; Swerdlow, R.H. Amyloid precursor protein processing and bioenergetics. Brain Res. Bull. 2017, 133, 71-79. [CrossRef] [PubMed]

114. Dawkins, E.; Small, D.H. Insights into the physiological function of the beta-amyloid precursor protein: Beyond Alzheimer's disease. J. Neurochem. 2014, 129, 756-769. [CrossRef] [PubMed]

115. Rogers, J.T.; Venkataramani, V.; Washburn, C.; Liu, Y.; Tummala, V.; Jiang, H.; Smith, A.; Cahill, C.M. A role for amyloid precursor protein translation to restore iron homeostasis and ameliorate lead $(\mathrm{Pb})$ neurotoxicity. J. Neurochem. 2016, 138, 479-494. [CrossRef] [PubMed]

116. Munoz, D.G.; Feldman, H. Causes of Alzheimer's disease. CMAJ 2000, 162, 65-72.

117. Alzheimer's, A. 2016 Alzheimer's disease facts and figures. Alzheimers Dement. 2016, 12, 459-509. [CrossRef]

118. Yamazaki, Y.; Zhao, N.; Caulfield, T.R.; Liu, C.C.; Bu, G. Apolipoprotein E and Alzheimer disease: Pathobiology and targeting strategies. Nat. Rev. Neurol. 2019, 15, 501-518. [CrossRef] [PubMed]

119. Corder, E.H.; Saunders, A.M.; Strittmatter, W.J.; Schmechel, D.E.; Gaskell, P.C.; Small, G.W.; Roses, A.D.; Haines, J.L.; Peri-cakVance, M.A. Gene dose of apolipoprotein E type 4 allele and the risk of Alzheimer's disease in late onset families. Science 1993, 261, 921-923. [CrossRef]

120. Saunders, A.M.; Strittmatter, W.J.; Schmechel, D.; George-Hyslop, P.H.; Pericak-Vance, M.A.; Joo, S.H.; Rosi, B.L.; Gusella, J.F.; Crapper-MacLachlan, D.R.; Alberts, M.J.; et al. Association of apolipoprotein E allele epsilon 4 with late-onset familial and sporadic Alzheimer's disease. Neurology 1993, 43, 1467-1472. [CrossRef]

121. Reiman, E.M.; Chen, K.; Liu, X.; Bandy, D.; Yu, M.; Lee, W.; Ayutyanont, N.; Keppler, J.; Reeder, S.A.; Langbaum, J.B.; et al. Fibrillar amyloid-beta burden in cognitively normal people at 3 levels of genetic risk for Alzheimer's disease. Proc. Natl. Acad. Sci. USA 2009, 106, 6820-6825. [CrossRef]

122. Ayton, S.; Faux, N.G.; Bush, A.I. Ferritin levels in the cerebrospinal fluid predict Alzheimer's disease outcomes and are regulated by APOE. Nat. Commun. 2015, 6, 6760. [CrossRef]

123. Butterfield, D.A.; Mattson, M.P. Apolipoprotein E and oxidative stress in brain with relevance to Alzheimer's disease. Neurobiol. Dis. 2020, 138, 104795. [CrossRef]

124. The Need for Early Detection and Treatment in Alzheimer's Disease. EBioMedicine 2016, 9, 1-2. [CrossRef]

125. Dixon, S.J.; Lemberg, K.M.; Lamprecht, M.R.; Skouta, R.; Zaitsev, E.M.; Gleason, C.E.; Patel, D.N.; Bauer, A.J.; Cantley, A.M.; Yang, W.S.; et al. Ferroptosis: An iron-dependent form of nonapoptotic cell death. Cell 2012, 149, 1060-1072. [CrossRef]

126. Cozza, G.; Rossetto, M.; Bosello-Travain, V.; Maiorino, M.; Roveri, A.; Toppo, S.; Zaccarin, M.; Zennaro, L.; Ursini, F. Glutathione peroxidase 4-catalyzed reduction of lipid hydroperoxides in membranes: The polar head of membrane phospholipids binds the enzyme and addresses the fatty acid hydroperoxide group toward the redox center. Free Radic. Biol. Med. 2017, $112,1-11$. [CrossRef] [PubMed]

127. Li, J.; Cao, F.; Yin, H.L.; Huang, Z.J.; Lin, Z.T.; Mao, N.; Sun, B.; Wang, G. Ferroptosis: Past, present and future. Cell Death Dis. 2020, 11, 88. [CrossRef] 
128. Chen, X.; Li, J.; Kang, R.; Klionsky, D.J.; Tang, D. Ferroptosis: Machinery and regulation. Autophagy 2021, 17, 2054-2081. [CrossRef] [PubMed]

129. Derry, P.J.; Hegde, M.L.; Jackson, G.R.; Kayed, R.; Tour, J.M.; Tsai, A.L.; Kent, T.A. Revisiting the intersection of amyloid, pathologically modified tau and iron in Alzheimer's disease from a ferroptosis perspective. Prog. Neurobiol. 2020, $184,101716$. [CrossRef]

130. Weiland, A.; Wang, Y.; Wu, W.; Lan, X.; Han, X.; Li, Q.; Wang, J. Ferroptosis and Its Role in Diverse Brain Diseases. Mol. Neurobiol. 2019, 56, 4880-4893. [CrossRef] [PubMed]

131. Ashraf, A.; Jeandriens, J.; Parkes, H.G.; So, P.W. Iron dyshomeostasis, lipid peroxidation and perturbed expression of cystine/glutamate antiporter in Alzheimer's disease: Evidence of ferroptosis. Redox Biol. 2020, 32, 101494. [CrossRef]

132. Silvestri, L.; Camaschella, C. A potential pathogenetic role of iron in Alzheimer's disease. J. Cell. Mol. Med. 2008, 12, 1548-1550. [CrossRef] [PubMed]

133. Choi, D.H.; Kwon, K.C.; Hwang, D.J.; Koo, J.H.; Um, H.S.; Song, H.S.; Kim, J.S.; Jang, Y.; Cho, J.Y. Treadmill Exercise Alleviates Brain Iron Dyshomeostasis Accelerating Neuronal Amyloid-beta Production, Neuronal Cell Death, and Cognitive Impairment in Transgenic Mice Model of Alzheimer's Disease. Mol. Neurobiol. 2021, 58, 3208-3223. [CrossRef]

134. Amit, T.; Avramovich-Tirosh, Y.; Youdim, M.B.; Mandel, S. Targeting multiple Alzheimer's disease etiologies with multimodal neuroprotective and neurorestorative iron chelators. FASEB J. 2008, 22, 1296-1305. [CrossRef]

135. Robert, A.; Liu, Y.; Nguyen, M.; Meunier, B. Regulation of copper and iron homeostasis by metal chelators: A possible chemotherapy for Alzheimer's disease. Acc. Chem. Res. 2015, 48, 1332-1339. [CrossRef]

136. Kontoghiorghe, C.N.; Kontoghiorghes, G.J. New developments and controversies in iron metabolism and iron chelation therapy. World J. Methodol. 2016, 6, 1-19. [CrossRef] [PubMed]

137. Sebastiani, G.; Wilkinson, N.; Pantopoulos, K. Pharmacological Targeting of the Hepcidin/Ferroportin Axis. Front. Pharmacol. 2016, 7, 160. [CrossRef] [PubMed]

138. Witcher, D.R.; Leung, D.; Hill, K.A.; De Rosa, D.C.; Xu, J.; Manetta, J.; Wroblewski, V.J.; Benschop, R.J. LY2928057, An Antibody Targeting Ferroportin, Is a Potent Inhibitor Of Hepcidin Activity and Increases Iron Mobilization In Normal Cynomolgus Monkeys. Blood 2013, 122, 3433. [CrossRef]

139. Sheetz, M.; Barrington, P.; Callies, S.; Berg, P.H.; McColm, J.; Marbury, T.; Decker, B.; Dyas, G.L.; Truhlar, S.M.E.; Benschop, R.; et al. Targeting the hepcidin-ferroportin pathway in anaemia of chronic kidney disease. Br. J. Clin. Pharmacol. 2019, 85, 935-948. [CrossRef]

140. Xie, Y.; Tan, Y.; Zheng, Y.; Du, X.; Liu, Q. Ebselen ameliorates beta-amyloid pathology, tau pathology, and cognitive impairment in triple-transgenic Alzheimer's disease mice. J. Biol. Inorg. Chem. 2017, 22, 851-865. [CrossRef] [PubMed]

141. Zhang, Z.; Kodumuru, V.; Sviridov, S.; Liu, S.; Chafeev, M.; Chowdhury, S.; Chakka, N.; Sun, J.; Gauthier, S.J.; Mattice, M.; et al. Discovery of benzylisothioureas as potent divalent metal transporter 1 (DMT1) inhibitors. Bioorg. Med. Chem. Lett. 2012, 22, 5108-5113. [CrossRef]

142. Dixon, S.J.; Stockwell, B.R. The role of iron and reactive oxygen species in cell death. Nat. Chem. Biol. 2014, 10, 9-17. [CrossRef] [PubMed]

143. Mandel, S.; Youdim, M.B. Catechin polyphenols: Neurodegeneration and neuroprotection in neurodegenerative diseases. Free Radic. Biol. Med. 2004, 37, 304-317. [CrossRef]

144. Fernando, W.; Somaratne, G.; Goozee, K.G.; Williams, S.; Singh, H.; Martins, R.N. Diabetes and Alzheimer's Disease: Can Tea Phytochemicals Play a Role in Prevention? J. Alzheimers Dis. 2017, 59, 481-501. [CrossRef]

145. Mazumder, M.K.; Choudhury, S. Tea polyphenols as multi-target therapeutics for Alzheimer's disease: An in silico study. Med. Hypotheses 2019, 125, 94-99. [CrossRef]

146. Zhao, H.F.; Li, N.; Wang, Q.; Cheng, X.J.; Li, X.M.; Liu, T.T. Resveratrol decreases the insoluble Abeta1-42 level in hippocampus and protects the integrity of the blood-brain barrier in AD rats. Neuroscience 2015, 310, 641-649. [CrossRef]

147. Cox, K.H.; Pipingas, A.; Scholey, A.B. Investigation of the effects of solid lipid curcumin on cognition and mood in a healthy older population. J. Psychopharmacol. 2015, 29, 642-651. [CrossRef] [PubMed]

148. Saad, M.A.; Abdel Salam, R.M.; Kenawy, S.A.; Attia, A.S. Pinocembrin attenuates hippocampal inflammation, oxidative perturbations and apoptosis in a rat model of global cerebral ischemia reperfusion. Pharmacol. Rep. 2015, 67, 115-122. [CrossRef]

149. Chen, X.; Gawryluk, J.W.; Wagener, J.F.; Ghribi, O.; Geiger, J.D. Caffeine blocks disruption of blood brain barrier in a rabbit model of Alzheimer's disease. J. Neuroinflamm. 2008, 5, 12. [CrossRef] [PubMed]

150. Cascella, M.; Bimonte, S.; Muzio, M.R.; Schiavone, V.; Cuomo, A. The efficacy of Epigallocatechin-3-gallate (green tea) in the treatment of Alzheimer's disease: An overview of pre-clinical studies and translational perspectives in clinical practice. Infect. Agent Cancer 2017, 12, 36. [CrossRef]

151. Ide, K.; Matsuoka, N.; Yamada, H.; Furushima, D.; Kawakami, K. Effects of Tea Catechins on Alzheimer's Disease: Recent Updates and Perspectives. Molecules 2018, 23, 2357. [CrossRef] [PubMed]

152. Jiang, T.; Sun, Q.; Chen, S. Oxidative stress: A major pathogenesis and potential therapeutic target of antioxidative agents in Parkinson's disease and Alzheimer's disease. Prog. Neurobiol. 2016, 147, 1-19. [CrossRef]

153. Anand, P.; Singh, B. A review on cholinesterase inhibitors for Alzheimer's disease. Arch. Pharm. Res. 2013, 36, 375-399. [CrossRef]

154. Ghosh, M.C.; Zhang, D.L.; Rouault, T.A. Iron misregulation and neurodegenerative disease in mouse models that lack iron regulatory proteins. Neurobiol. Dis. 2015, 81, 66-75. [CrossRef] 
155. Hower, V.; Mendes, P.; Torti, F.M.; Laubenbacher, R.; Akman, S.; Shulaev, V.; Torti, S.V. A general map of iron metabolism and tissue-specific subnetworks. Mol. Biosyst. 2009, 5, 422-443. [CrossRef] [PubMed]

156. Lieu, P.T.; Heiskala, M.; Peterson, P.A.; Yang, Y. The roles of iron in health and disease. Mol. Asp. Med. 2001, 22, 1-87. [CrossRef]

157. Seeley, W.W.; Crawford, R.K.; Zhou, J.; Miller, B.L.; Greicius, M.D. Neurodegenerative diseases target large-scale human brain networks. Neuron 2009, 62, 42-52. [CrossRef] [PubMed]

158. Dugger, B.N.; Dickson, D.W. Pathology of Neurodegenerative Diseases. Cold Spring Harb. Perspect. Biol. 2017, 9, 7. [CrossRef] [PubMed]

159. Roubroeks, J.A.Y.; Smith, R.G.; van den Hove, D.L.A.; Lunnon, K. Epigenetics and DNA methylomic profiling in Alzheimer's disease and other neurodegenerative diseases. J. Neurochem. 2017, 143, 158-170. [CrossRef] [PubMed]

160. Liu, Y.; Nguyen, M.; Robert, A.; Meunier, B. Metal Ions in Alzheimer's Disease: A Key Role or Not? Acc. Chem. Res. 2019, 52, 2026-2035. [CrossRef]

161. Nikseresht, S.; Bush, A.I.; Ayton, S. Treating Alzheimer's disease by targeting iron. Br. J. Pharmacol. 2019, 176, 3622-3635. [CrossRef]

162. Thirupathi, A.; Chang, Y.Z. Brain Iron Metabolism and CNS Diseases. Adv. Exp. Med. Biol. 2019, 1173, 1-19. [PubMed]

163. Morris, G.; Berk, M.; Carvalho, A.F.; Maes, M.; Walker, A.J.; Puri, B.K. Why should neuroscientists worry about iron? The emerging role of ferroptosis in the pathophysiology of neuroprogressive diseases. Behav. Brain Res. 2018, 341, 154-175. [CrossRef] [PubMed]

164. Leong, Y.Q.; Ng, K.Y.; Chye, S.M.; Ling, A.P.K.; Koh, R.Y. Mechanisms of action of amyloid-beta and its precursor protein in neuronal cell death. Metab. Brain Dis. 2020, 35, 11-30. [CrossRef] [PubMed] 